\title{
分子科学研究所の装置開発および 他機関との技術交流
}

Equipment Development in Institute for Molecular Science and Technology Exchange with Other Institutes

\section{青山正樹** 水谷伸雄** 近藤聖彦*** \\ 高田紀子** 木村幸代** 菊地拓郎 ${ }^{* *}$}

Masaki AOYAMA, Nobuo MIZUTANI, Takuhiko KONDO, Noriko TAKADA, Sachiyo KIMURA and Takuro KIKUCHI

Key words technical associate, personnel exchange, spectroscope, precision machining, micro-channel, lithography, electroforming

\section{1. は じめに}

装置開発室は分子科学研究所の研究施設の一つとして 1975 年の研究所創設と同時に設置され, (1)分子科学の新 展開に必要な新しい装置を開発する, (2)日常の実験に必要 な部品類を迅速に製作する一という二つの役割を担って いる，創設時からクライオスタット，各種真空容器，極端 紫外光施設 (UVSOR) に設置する分光器を含むビームラ イン, NMR プローブなど, 市販されていない物性測定装 置の製作を行っている。また，従来の機械工作に加え， 2000 年ごろからはバイオおよびナノサイエンスなどの研 究で必要とされる, 微細な形状を有する実験機器の製作が 求められるようになり, これに対応するためマイクロ形状 加工の取り組みを始めた。現在はより微細な形状のデバイ ス製作にも対応できるよう，リソグラフィによる製作も行 うなど，新しいニーズへの対応も随時進めている.

本解説では，これまで装置開発室で製作されてきた実験 装置の紹介および装置開発室職員の他機関との人事および 技術交流を紹介する。

\section{2. 装置開発室の概要}

装置開発室は室長と 12 名の技術職員および技術支援員 で構成される。機械設計, 機械工作およびリソグラフィを 行うメカトロニクスセクションに 8 名, 電子回路設計, ソ フトウエア開発および $3 \mathrm{D}$ プリンタによる製作支援を行う エレクトロニクスセクションに 4 名が配置されており, 両 セクションを合わせて年間 300 件を超える所内からの製作 依頼に対応している。一方, 2005 年からは所外の分子科 学および関連する研究分野の研究者からの実験機器製作に

*原稿受付 令和 2 年 6 月 25 日

*自然科学研究機構分子科学研究所装置開発室（愛知県岡崎市明大寺町字西 郷中 38)

**正 会 員然科学研究機構分子科学研究所装置開発室（愛知県岡崎市明 大寺町字西郷中 38)
も審査を経た上で対応している。また，2013 年度からは ナノテクノロジープラットホームを空口としてフォトリソ グラフィ技術によるマイクロ流路などの微細構造物の製作 依頼や設備の利用にも対応し, 大学共同利用機関として全 国の大学・研究機関への技術支援を広く行っている。さら に今年度からは民間企業からの装置利用・技術開発・設計 製作依頼にも対応できるよう空口を設けている.

ホームページ（http://edcweb.ims.ac.jp/index.html）に 利用の案内が記載されているのでご参照いただきたい.

\section{3. 製作事例の紹介}

今回は主にメカトロニクスセクションで製作された実験 装置を紹介する.

装置開発室では 1983 年の UVSOR の立ち上げにともな い, いくつかの分光器の設計製作を担当した。図 1 は UVSOR に設置された瀬谷浪岡型分光器, 図 2 は複合入射 型分光器である. 複数のグレーティングを切り替えて使用 するためのグレーティング交換機構, 波数走査を精密に行 うためのサインバー駆動機構，軸外の放射光をカットする スリット機構など, 前置鏡室, 分光器, 後置鏡室, 試料 室, 各駆動制御回路など一連のビームラインの設計から製

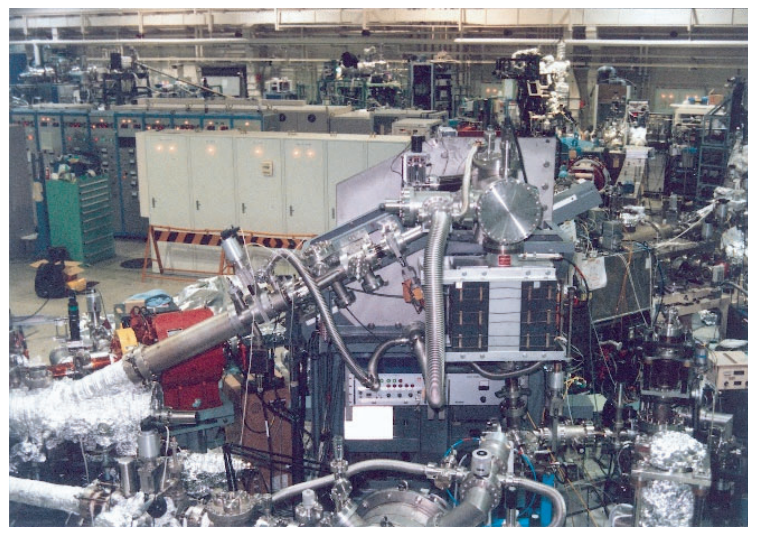

図 1 UVSOR に設置された瀬谷浪岡型分光器 


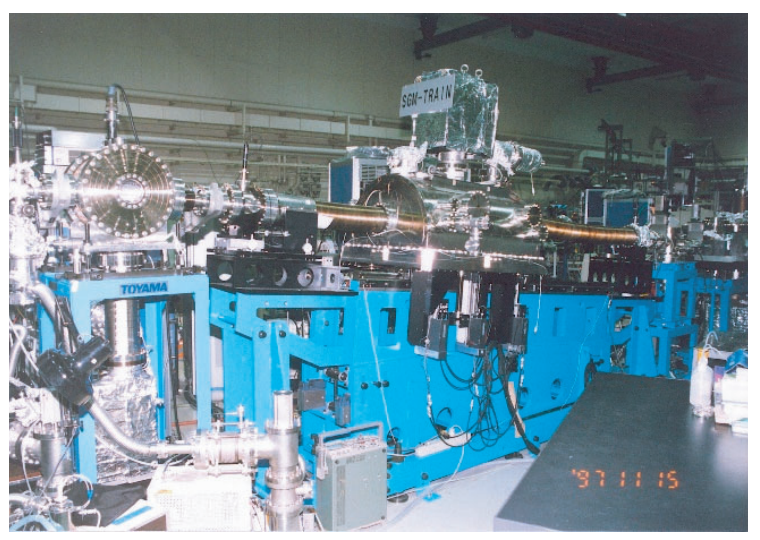

図 2 複合入射型分光器

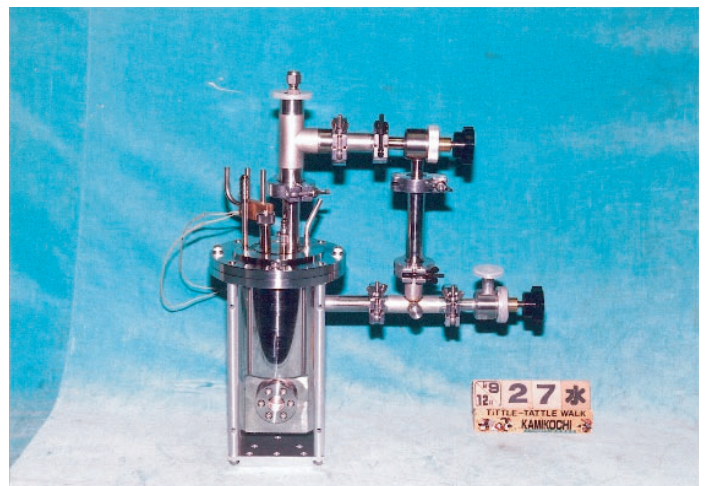

図３＼cjkstart試料加熱冷却クライオスタット

作，設置まで担当した。当時は真空に関する知識も少なく 超高真空に関する技術を学びながら分光器を設計した。こ れらの設計・製作を行う過程で，超高真空に必要な構造材 料から真空ポンプに関する知識，チェンバー製作に必要な 溶接技術や真空内での精密な駆動技術など，超高真空装置 の製作ノウハウを蓄積した。瀬谷浪岡型分光器は 1995 年 まで，複合入射型分光器は 2012 年まで UVSOR 施設の共 同利用ポートで使用され多くの研究成果を上げている.

図 3 はX X 線ラマン散乱により局所構造解析を行うため のクライオスタットである。試料を $500^{\circ} \mathrm{C}$ ま゙加熱しガス と反応させ，そのまま液体窒素温度まで泠却し 10 時間ほ ど冷却保持できる装置である。従来の装置は加熱反応部と 冷却測定部を別のチェンバーに設けていたが，製作担当者 のアイデアで加熱反応および冷却を一つの試料室内で行う ことを可能とした。また，これ以外にも多くのクライオス タットの製作を手掛けており，アルゴンアーク溶接，電子 ビーム溶接および銀ロウ付けなど接合に関する技能，組み 立て順序が問題とされることが多いクライオスタット製作 ノウハウを得て，その後製作依頼が増加した固体 NMR プ ローブなどの機器製作に適用した。

2000 年ごろからマイクロ流路などの微細な溝構造を有 する実験機器の製作依頼が増加し, 当室で所有する一般的 な NC フライス盤を使って製作してきた．図４はタンパク
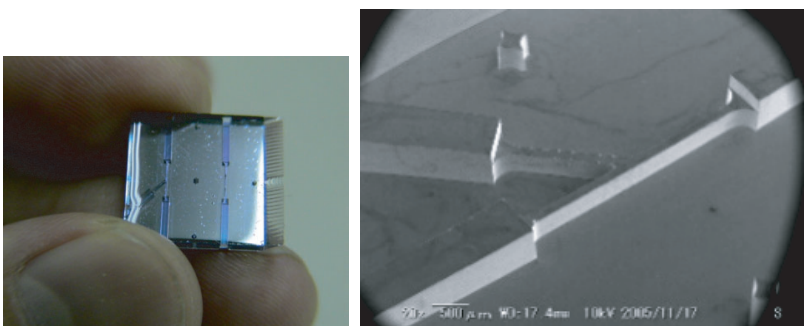

図４ママイクロ流路チップ (左) と PDMS 成形用モールド (右)
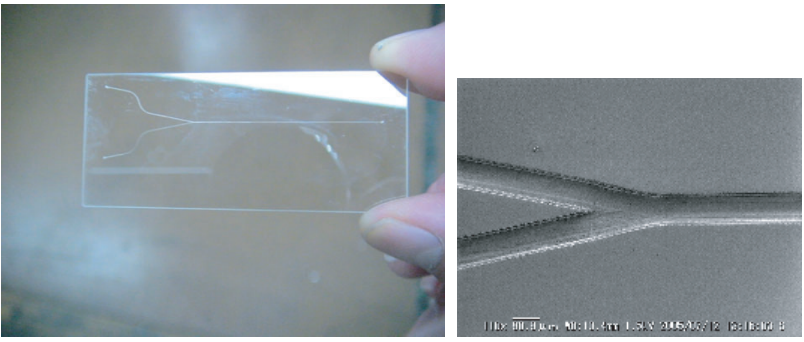

図 5 ガラス製マイクロ流路（左）と SEM 画像（右）

質選別のテストに使用するためのマイクロ流路チップと流 路製作用金型の SEM である。切削加工により流路形状の 凸型を製作し，そこにシリコーンゴムの一種である PDMS（ポリジメチルシロキサン）を流し达み，溝形状を 転写しシリコン基板に貼りつけた。金型の流路となる凸部 は幅 $100 \mu \mathrm{m}$, 高さ $400 \mu \mathrm{m}$, 合流部のコーナー R は $50 \mu \mathrm{m}$ である。図 5 には触媒創成の実験に使用するガラス製マ イクロ流路チップの外観および溝部の SEM を示す。当時 はフォトエッチングの設備を所有していなかったため, ホ ウケイ酸ガラスに幅 $100 \mu \mathrm{m}$, 深さ $40 \mu \mathrm{m}$ の溝を, 電着ダ イヤモンド砥石を設置した NCフライス盤で製作した。

マイクロ流路は, タンパク質の時間分解測定や X 線吸 収分光実験などに使用される。分子科学研究所において夕 ンパク質等を対象とする研究テーマが増加するにともな い，製作依頼が増加した。しかし，合流部のコーナー R が実験上好ましくないケースや, より微細な溝形状の要求 など機械加工によるモールド製作では対応が困難な製作依 頼が増加してきた。そのためSU-8レジストによるモール ド作製や，ホウケイ酸ガラス拈よび石英ガラスのケミカル エッチングによる製作などリソグラフィ技術を導入した. さらに最近ではフォトリソグラフィで製作した微細パ夕ー ンにニッケルおよび銅電鋳を行い, 真空蒸着などで使用す るメタルマスクも所内で製作が可能となっている. 図 6 はリソグラフィにより製作した実験デバイス，図７はメ タルマスクの外観である.

一方, 機械加工においても, より高精度な機器製作の要 求が生まれている。細胞のイオン電流計測に使用する多チ ヤンネルプレーナー型バイオセンサー基板は, 厚み 200 $\mu \mathrm{m}$ のアクリル板に電極構造を構成するための $10 \mu \mathrm{m}$ の薄 膜部を多数形成する必要がある。そこで図 8 に示すよう 


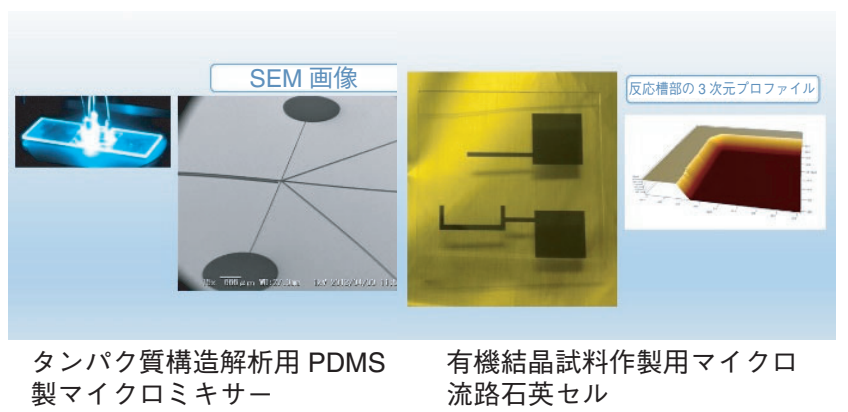

図６リソグラフィによる製作例
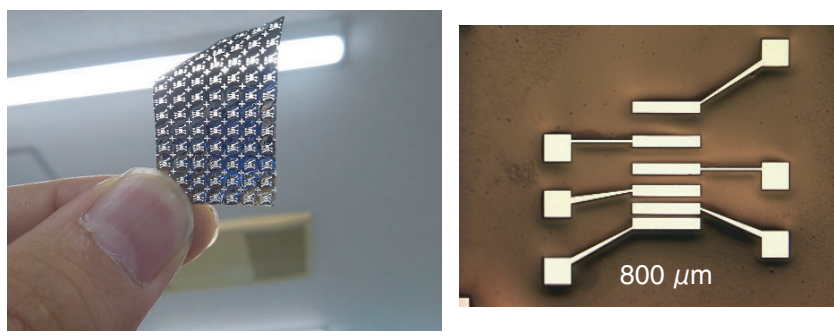

図 7 ニッケル電鋳で製作したメタルマスク

(左) と拡大写真（右）

な微小な突起の付いた高精度な金型を用いたホットエンボ ス加工により，薄膜部を形成することを検討した． $10 \mu \mathrm{m}$ の均一な薄膜部厚さを得るには, 金型の突起先端部は高精 度な平滑面が必要である。また，突起高さがそろっていな いとすべての薄膜部を正確な厚みに形成することが難し い，そのため, 一般的な精度の工作機械ではなく超精密加 工機によりこの金型の製作を行った，当室では超精密加工 機やナノレベルの加工精度を得るような加工技術を所有し ていなかったため, 理化学研究所の大森整先生の設備を利 用させていただき技術指導を仰ぎながら金型製作を行っ た．図９に製作したホットエンボス用精密金型，図 10 に 成形されたアクリル基板を示す。成形条件によっては薄膜 部にクラックが生じることもあったが，適切な条件で成形 を行うことで安定的に $10 \mu \mathrm{m}$ の薄膜部をもつ基板を製作 することが可能となった，また，超精密加工技術を学んだ ことにより，所内から金属ミラーの製作相談も受けるよう になり, 逆光電子分光用アルミミラーやレーザー分子分光 で使用する回転楕円集光ミラーなどを, 国立天文台先端技 術センターの施設利用による協力を頂いて製作した。

さらに近年は, 従来の機械設計・機械工作に加えて, 異 なる分野の技術が必要な実験装置の設計・製作が求められ る機会がある。装置の詳細については諸般の事情で本稿で は説明を省略するが，結晶どうしを貼り合わせるための装 置やサンプルに磁場を印加するための装置など，真空技術 や機械要素技術だけでなくプラズマプロセスや磁気回路設 計などに関する知識や技術が必要とされた。特に磁場印加 装置の製作では，これまで行っていなかった磁場解析を取 り入れ, 飽和磁束密度などを確認しながら磁路形状設計を

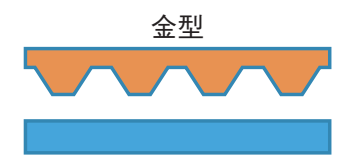

\section{アクリル基板}
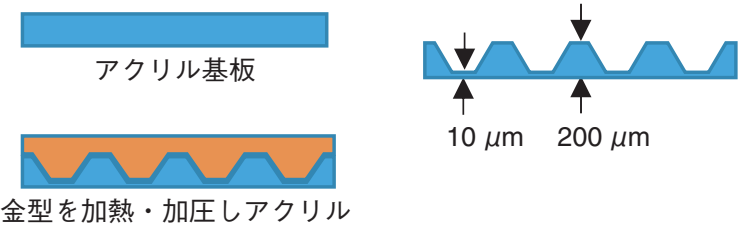
金型を加熱・加圧しアクリル
基板を成形

図 8 ホットエンボス加工

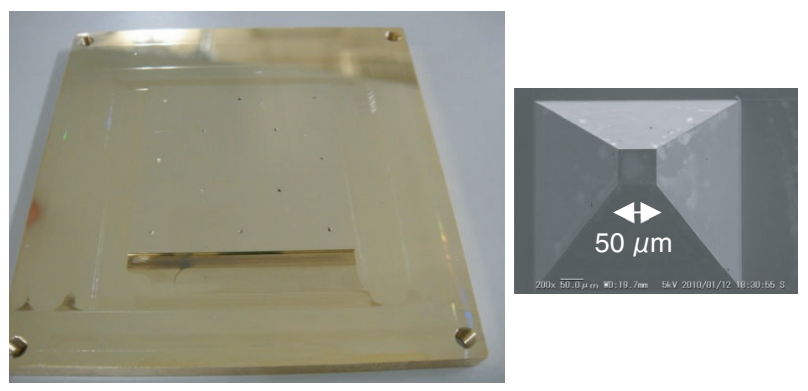

図 9 製作した金型の外観と突起部の SEM 像
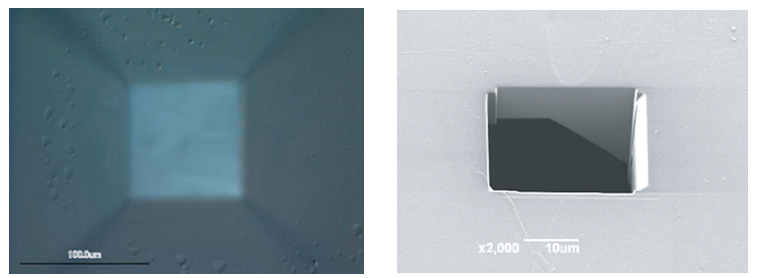

図 10 成形したアクリル基板平面側（左）とFIB 加工した $10 \mu \mathrm{m}$ 薄膜部の SEM（右）

行った。最近では多くの実験装置の設計製作には，このよ うに解析ソフトを活用して依頼者と緊密に打ち合わせを行 いながら新しい装置の開発に取り組んでいる。

本報告ではメカトロニクスセクションの製作事例のみ紹 介したが，装置開発室の HP（http://edcweb.ims.ac.jp/ product.html）にはエレクトロニクスセクションの製作品 も紹介されているのでぜひご覧いただきたい。

\section{4. 他機関との人事交流および技術交流について}

\section{1 人事交流について}

分子科学研究所装置開発室では全国に先駆けて 1995 年 から 2004 年の間に名古屋大学理学部装置開発室との間で 3 件の人事交流を行った。 また, 北陸先端大学院大学創設 時には工作室の立ち上げのために技術職員 1 名が 3 年間出 向して新規採用職員の教育を行い, 工作室業務を軌道に乗 せた。また，2016年には宇宙科学研究所に筆者のうち 1 名（青山）が 1 年間出向し, 宇宙科学研究所に新たに設置 された先端工作技術グループの立ち上げに協力した．これ 
ら人事交流などでは，所属する機関で取り扱う技術とは異 なる技術に触れる機会も多く，身につけてきた技術を別の 側面から見ることで，さらに高めていくヒントが得られる など学ぶことが多い。 また，技術者どうしの横のつながり を得られ, 組織の違いや仕事の進め方, 使用する道具の違 いなど，技術以外にも新しく体験することが多く，技術者 として大きく幅を広げることができる。これらは大学・研 究機関で研究をサポートする人材育成には必要なことであ り，今後さらに技術職員の人事交流が活発に行われるよう になっていくことを期待する.

\section{2 技術交流について}

分子研では大学共同利用機関として全国の大学・研究機 関の技術職員に対して多くの技術研鑽の場を設け，活発な 技術交流が行われている。その一つが現在全国規模で大 学・研究機関の持ち回りで開催されている技術研究会であ る. 1975 年に分子科学研究所の初代技術課長として名古 屋大学理学部工作室から赴任した高橋重敏氏が, 学術研究 を発展させるためには研究者と協働する高度な技術者の存 在が重要であるとの考えから, 1976 年に全国で初めて技 術職員の研鑽や技術習得の場として, 第 1 回技術研究会を 開催したのが始まりである。

受け入れ研修は, 他機関からの要望に応じて分子研の施 設などを使って行う研修制度で, 研修内容および研修期間 は先方と相談して実施している。来所する交通費, 滞在費 なども必要に応じて分子研で負担している。装置開発室で もこれまで多くの受け入れ研修を行い, 全国の大学・研究 機関の技術職員の技術研鑽に協力している.

技術課セミナーは各研究施設で必要とされる専門技術に 関する知見を深めることを目的に, その分野に精通した先 生方を招聘している。他機関の技術職員にも開催をお知ら せし受け入れ研修の一つとして参加いただいている。装置 開発室でもこれまで多くのセミナーを企画実施してきた.

また,リソグラフィ技術立ち上げ時には，これまでまっ たく取り扱ったことのない技術分野であったため，機関を 超えて技術的な相談ができる「横のつながり」が必要とさ れた。 そこで，各機関でリソグラフィに携わっている技術 職員に交流を呼び掛け，さまざまなアドバイスを受けた り，情報交換をしたりする緊密な技術交流の場として，微 細加工に関する技術サロン会を開催している.

\section{5.おわりに}

装置開発室では製作依頼に応える一方, 将来の研究二ー ズを見据えた新しい技術の導入も, 装置開発室の重要な業 務と位置づけ, 自主的に進めている。現在は, 研究室で行 われているピペット作業などの試料作製の工程をロボット に行わせるために, AI 画像認識による液量制御やさまざ
まなガラス器具などの把持や操作などに必要な要素技術に 取り組んでいる.

技術職員は幅広くかつ高度な技術を身につけることがで き，また研究者と協働して日本の学術研究の発展に貢献で きる魅力的な職業である。一人でも多くの方が技術職員の 道を目指すことを期待している。
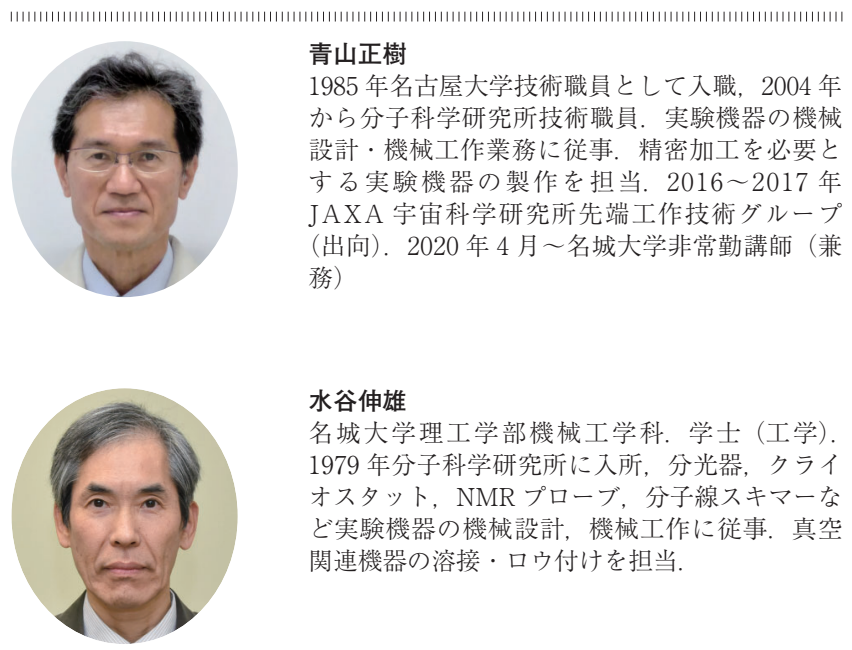

\section{水谷伸雄}

名城大学理工学部機械工学科. 学士 (工学). 1979 年分子科学研究所に入所, 分光器, クライ オスタット, NMR プローブ, 分子線スキマーな ど実験機器の機械設計, 機械工作に従事. 真空 関連機器の溶接・ロウ付けを担当.

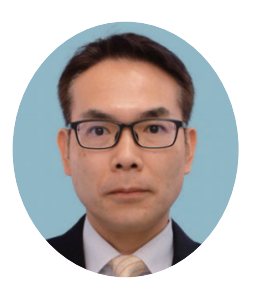

\section{近藤聖彦}

福井大学大学院工学研究科博士前期課程機械工 学専攻修了. 修士. 1996 年分子科学研究所に入 所, 主に分子科学に関する装置の設計製図, 実 験に使用する部品加工に従事, 近年はレーザ開 発に関する実験用部品の設計製図を担当.

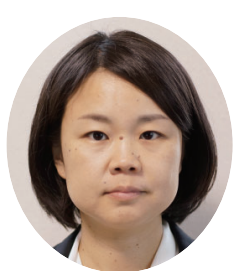

\section{高田紀子}

東京農工大学農学研究科修士課程応用生命化学 専攻修了. 民間企業を経て 2009 年分子科学研究 所に入所. 所内外から依頼されるマイクロ流路 などのリソグラフィによる実験機器の製作を担 当.

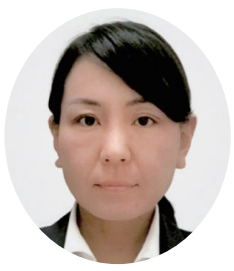

\section{木村幸代}

弘前大学大学院理工学研究科知能機械システム 工学専攻修了。修士，民間企業を経て 2016 年に 分子科学研究所に入所. 実験機器の機械設計, 機械工作に従事. 現在はリソグラフィによる実 験機器の製作を担当.

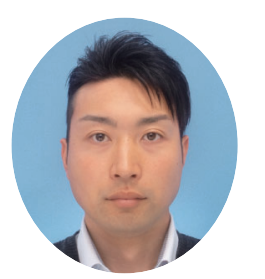

\section{菊地拓郎}

信州大学理学部物理科学科卒業, 学士 民間企 業を経て 2018 年分子科学研究所入所. 実験機器 の機械設計, 機械工作に従事. 電気鋳造, メッ キなどの表面処理技術を担当. 